\title{
Fungi against insects and contrariwise as biological control models
}

\author{
Waill A. Elkhateeb ${ }^{1 *} \mathbb{D}$, Kareem M. Mousa ${ }^{2}$, Marwa O. ELnahas ${ }^{1}$ and Ghoson M. Daba ${ }^{1}$
}

\begin{abstract}
Background: Biological control of insects is the current goal of modern researches to avoid using the harmful chemicals. Some fungi are capable of infecting and killing insects and, hence, are commonly known as entomopathogenic fungi (EPF). On the other hand, some insects can kill harmful fungal strains using their products such as peptides. Hence, the aim of this review article is to highlight the use of EPF as biocontrol tools against each other.

Results: EPF are generally characterized by having a wide range of hosts which made them the perfect candidate for biological control missions. They are existing in abundance in the environment and involved in plenty of environmental interactions. They have prestigious enzymatic machinery and toxins that contribute as killing tools. Moreover, after penetrating the insect, the expanded vegetative growth of hyphal bodies enabling the invasion of the fungi throughout the entire tissues of host insect cause physic, histolytic, and pathologic changes ultimately leading to the death of the host insect. On the other hand, some insects can kill harmful fungal strains using their secreted products such as peptides.

Conclusion: In this review, the use of fungi and insects as biological control agents against each other was described. Furthermore, the history of using EPF for this purpose, their killing mechanism, host range, and the factors affecting EPF virulence were highlighted. Moreover, the role of insect's immunology and some insect's products as antifungal agents was presented focusing on peptides with biological activities against fungi. Finally, future prospects concerning the use of insects and fungi in biological control process were discussed.
\end{abstract}

Keywords: Insect pests, Entomopathogenic fungi, Biological control, Antifungal peptides

\section{Background}

Insect pests cause enormous damage to different agricultural crops. Synthetic chemical pesticides have been used for insect pest control for over 50 years. However, development of resistance against insecticides, pest rebirth, and raising concerns about the environmental impacts of agricultural inputs give urgency to screening and investigation for alternative, biologically based forms of pest control. Insects like other living organisms have their enemies in nature such as microorganisms, especially some fungal species, which can parasitize insects

\footnotetext{
*Correspondence: waillahmed@yahoo.com

${ }^{1}$ Chemistry of Natural and Microbial Products Department, Pharmaceutical Industries Division, National Research Centre, Dokki, Giza 12622, Egypt Full list of author information is available at the end of the article
}

and cause severe epizootics than what bacteria and viruses can do. During the late nineteenth and early twentieth centuries, many entomopathogenic fungi (EPF) have been examined as possible control agents for various insect pests. About 750 species of EPF were reported to infect insects or mites (Sujeetha and Sahayaraj 2014). The most important groups belong to the class Hyphomycetes, within genera like Beauveria, Metarhizium, Verticillium, Paecilomyces, Nomuraea, and Hirsutella (Butt 2002). Also, the sexual (teleomorph) state (e.g., Cordyceps, Entomophthora, Zoophthora, Pandora, Entomophaga) belongs to the order Entomophthorales. Most of the EPF are found within the deuteromycetes and entomophthorales. EPF such as Metarhizium anisopliae and Beauveria bassiana are well characterized in respect

\section{Springer Open}

() The Author(s). 2021 Open Access This article is licensed under a Creative Commons Attribution 4.0 International License, which permits use, sharing, adaptation, distribution and reproduction in any medium or format, as long as you give appropriate credit to the original author(s) and the source, provide a link to the Creative Commons licence, and indicate if changes were made. The images or other third party material in this article are included in the article's Creative Commons licence, unless indicated otherwise in a credit line to the material. If material is not included in the article's Creative Commons licence and your intended use is not permitted by statutory regulation or exceeds the permitted use, you will need to obtain permission directly from the copyright holder. To view a copy of this licence, visit http://creativecommons.org/licenses/by/4.0/. 
to pathogenicity to several insects, and they have been used as agents for the biological control of agriculture pests worldwide. The EPF can be collected from naturally infested dead cadavers and also from the soil (Sahayaraj and Karthick Raja 2011). The use of EPF as potential candidates for insect's biological control is based on the fact that they are an important and widespread component of most terrestrial ecosystems. There are about 1.5 million types of fungi, of which nearly 400 species can infect animals and less than 400 species can infect humans. Nevertheless, some fungal diseases can result from opportunistic fungi. In general, a fungi cell wall is made up of chitin, $1,3-\beta$ - and $1,6-\beta$-glucans, and proteins, together with other polymers. The cell wall composition is characterized by being so flexible and changes at regular basis during the cell separation. It was reported that the cell wall is associated with several hydrolytic enzymes, which are responsible for maintaining the cell wall flexibility beside their importance for crosslinking of polymers as well as cell division. However, fungi are eukaryotes, which mean that there are many common features in the structure of their cells together with those of humans. There are four types of antifungal agents that are commercially available: azoles, echinocandins, polenes, and pyrimidine analogs (Tawara et al. 2000).

Continuous approaches have been developed to improve biological control as safe alternative to the use of fungicidal agents. Researchers found that many insects produce different compounds, which have antifungal activity. Numerous biologically active peptides have been produced by many insects and interestingly these peptides show wide biological activities as promising antibacterial, antifungal, and antiviral agents (Mishra and Wang 2012). Peptides showing promising antifungal activities include drosomycin produced by the common fruit fly Drosophila melanogaster (Da Silva et al. 2003), termicin produced by termites (Khaleel et al. 2013), heliomycin produced by the tobacco budworm Heliothis virescens (Fehlbaum et al. 1994), gallerimycin isolated from the greater wax moth "Galleria mellonella" larvae (González-Santoyo and Córdoba-Aguilar 2012), and cecropins A and B from the giant silk moth Hyalopora cecropia (Schuhmann et al. 2003).

In this review, the potential use of fungi and insects as biological control agents against each other was highlighted. Describing the history of using EPF, their killing mode, host range, and the factors affecting EPF virulence were studied. Moreover, the role of some insect's products as antifungal agents was presented focusing on peptides with biological activities against fungi. Finally, future prospects concerning the use of those organism's products in biological control process were discussed.

\section{Main text}

\section{Fungi as antiinsect}

Enormous application of pesticides not only excesses the cost of pest control, but also results in environmental hazards and pollution; also, arthropod pests are known to develop resistance to chemical pesticides; researchers have often resort to incorporate alternative control conductance to minimize injuries caused by them. In the previous 50 years, control of pest insects using EPF been received much attention from researchers and a large number of commercial products came into sight (Faria and Wraight 2007). Fungal pathogens play a vital role in suppressing insect population dynamics. Microbial control has been used as a part of IPM programs in many countries, including the African countries with a long history of projects, for example, the expansion of "Green Muscle" was the first procedural for the application of mycoinsecticides in Africa to control insect pests (Maina et al. 2018).

Interestingly, many of the potent EPF are insect generalists (Moonjely et al. 2016). Till the first decade of the second millennium, more than 110 commercial products based on EPF were developed in different multinational agricultural chemical companies, such as Bayer, BASF, Monsanto, DuPont, and Arysta (Ravensberg 2015). Majority of those products was based on the 2 fungal strains, B. bassiana and M. anisopliae sensu lato (Faria and Wraight 2007). The remaining products are incorporating the fungal species, B. brongniartii, Isaria farinosus, I. fumosorosea, Lecanicillium muscarium, L. lecanii, and L. longisporum (Jaronski and Mascarin 2017). The potent fungus, $B$. bassiana, has been extensively used in fighting harmful insects attacking economically important crops such as cotton, maize, and wheat (Lopez et al. 2014). Also, it is used against insects invading crops of poppy, banana, and white jute (Biswas et al. 2013).

\section{History of using EPF}

Accentuation for the history of using organisms in the field is comparatively elusive, but it seems that the first earliest demonstration of the EPF was done by Agostino Bassi (1773-1856) who noticed that the larvae of the silkworm moth, Bombyx mori (Linn.), suffered from a disease. According to the color of the conidial layer protrudes from insect cuticle, he named it the white muscardine (Zimmermann 2007). Further studies were then effectuated by the naturalist Balsamo-Crivelli, who described it as Botrytis bassiana, later changed to Beauveria bassiana (Rehner and Buckley 2005). This was the first microorganism recognized as animal pathogen; thereafter, many researchers had proofed that fungi could be used against pest insects (Audoin 1837; Pasteur 1874). However, Elie Metchnikoff (1845-1916), in Russia discovered the green muscardine when he investigated 
the wheat cockchafers and identified it as Entomophthora anisopliae, which changed subsequent to Metarhizium anisopliae (Vega et al. 2009).

\section{Main text}

Fungi infection and mode of action

Infection process and mode of action of the EPF have been precisely defined in a considerable number of publications. Researchers unanimously documented 2 ways of spores' mobility to infect their host insect, (Akbari et al. 2014) as a result of its small size, the conidia's powdery clusters are easy to transport by air (Nolard 2004) or water (Hageskal et al. 2006) till meet its host, and (Almeida and Pokorny 2012) insect infected with fungus itself is considered to be a mechanical carrier that can easily transmit fungi to the intact individuals by direct friction (Ambethgar 2009) or by the excretion of viable conidia in their fecal droppings (Bruck and Lewis 2002). EPF percutaneously attack their hosts; hence, the infection pathway comprises the following 6 stages: adhesion of the spores; germination; penetration through integument, wounds, or trachea; hemolymph colonization, in the meantime, fungus attempts to overcome the host immune reactions; hyphal formation and proliferation; and sporulation and new conidia outgrowth (Leao et al. 2015).

Fungus penetrates cuticle through non-sclerotized areas, wounds, and trachea or via mouthparts. Penetration process accomplishes by mechanical and chemical means including several enzymes. Some fungi have become known what types of enzymes that they produce, e.g., B. bassiana is known to produce chitinases, proteases, and lipases (Zimmermann 2007), while others like $M$. acridium, for example, are still vague. The host insect exhibits humoral and cellular immune reactions in order to withstand fungi penetration such as production of phenoloxidase, which leads to pathogens melanization (Amparyup et al. 2013), hemocytes (Lavine and Strand 2002), encapsulation, excretion of antimicrobial peptides, phagocytosis, nodule formation (Hajdušek et al. 2013), and antifungal compounds (Zimmermann 2007). On the other side, fungi produce a set of enzymes and toxins to degrade the insect cuticle (Santi et al. 2010) in a collision, which will determine the successfulness of penetration process. After successful penetration process, hyphae exist in the haemolymph forming asexual fungal spore, i.e., blastoconidia. An expanded vegetative growth of hyphal bodies is enabling the invasion of the fungi throughout the entire tissues of host insect causing physic, histolytic, and pathologic changes ultimately leading to the death of the host insect after 3-7 days post infection (Zimmermann 2007; Shahid et al. 2012).

\section{Host range}

According to the number and diversity of infectious insect hosts, host range of EPF can be determined.
Scholars defined 2 types of host ranges; first is the ecological host range that refers to the number of insect species that pathogen could successfully infect under field conditions, while the second is the physiological host range, in which an EPF is able to infect under laboratory condition (Hajek and Goettel 2007). The ecological host range is more trustable as it conflicts the realistic risk for the environment. EPF have diverse host ranges as many insect orders can be infected by them; however, Lepidoptera, Diptera, Orthoptera, Coleoptera, Hymenoptera, and Hemiptera are the most common ones (Ramanujam et al. 2014). Most of them are capable of infecting a wide range of insect hosts; however, a few have an exiguous host range (Faria and Wraight 2007). Those who have a narrow physiological or ecological range of host insects are usually strenuous to mass produce (Gryganskyi et al. 2013). For example, EPF belong to the order Entomophthorales, which includes 4 families, Ancylistaceae, Completoriaceae, Entomophthoraceae, and Meristacraceae, which are capable of infecting a few hosts. While the fungus that belongs to order Hypocreales has 8 families and has a broad range of host insects (Faria and Wraight 2007). For example, the EPF B. bassiana (Hypocreales: Cordycipitaceae) has an exceedingly considerable host list of more than 700 insect species from different orders (Table 1) (Goettel et al. 2000; Zimmermann 2007; Meyling et al. 2009).

\section{Factors affecting EPF virulence}

EPF are involved in plenty of environmental interactions that affect it in multiple manners. The prosperity of EPF in the environment relies on conidial viability and to produce a suitable propagule (Olivera and Neves 2004). This ability contingent on many factors, the species and age of the arthropod host in this regard, is a key consideration in fungal success (Alves da Silva et al. 2015). Furthermore, the difference in host plant species may modulate the susceptibility of insect pest towards EPF (Ocampo-Hernández et al. 2019). The role of insect host species in inhibiting or stimulating the efficiency of EPF is due to the numerous defensive antimicrobial compounds within the cuticle of host insect that fungi have to overcome, in order to a successful virulence (Amparyup et al. 2013; Pedrini et al. 2013). Thus, EPF virulence is markedly in a relation with rapid germination on host insect cuticle. In order to have a successful germination after the attachment of fungi with the insect cuticle, it is essential for the fungi to confront with its favorable conditions of temperature and humidity. Environmental factors, i.e. temperature, sunlight, and humidity, are among the most important abiotic factors, which profound influence on the growth and virulence of a pathogen. It is well known that temperature and relative humidity significantly influence the survival, 
Table 1 Examples of insect pest species successfully controlled by the use of B. bassiana and M. anisopliae

\begin{tabular}{|c|c|c|c|}
\hline Fungus & Host insect & Host order & References \\
\hline \multirow[t]{22}{*}{ Beauveria bassiana } & Fire ants, Solenopsis invicta & Hymenoptera & Uma Devi et al. (2008) \\
\hline & Weaver ant, Oecophylla smaragdina & & \\
\hline & Armyworm, Spodoptera litura & Lepidoptera & Ullah et al. (2019) \\
\hline & European corn borer moth, Ostrinia nubilalis & & Cagáň and Uhlík (1999) \\
\hline & Diamondback moth Plutella xylostella & & Correa-Cuadros et al. (2014) \\
\hline & Maize Stem Borer, Chilo partellus & & Sufyan et al. (2019) \\
\hline & Silkworm, Bombyx mori & & Hou et al. (2013) \\
\hline & Sugar cane borer, Diatraea saccharalis & & Maurer et al. (1997) \\
\hline & Potato beetle, Leptinotarsa decemlineata & Coleoptera & Klinger et al. (2006) \\
\hline & Squash beetle, Epilachna vigintioctopunctata & & Hassan et al. (2019) \\
\hline & Yellow fever mosquito, Aedes aegypti & Diptera & Devi et al. (2006) \\
\hline & Banded blister beetle, Mylabris pustulata & Homoptera & Uma Devi et al. (2008) \\
\hline & Bird cherry-oat aphid, Rhopalosiphum padi & & Hesketh et al. (2008) \\
\hline & Cowpea aphid, Aphis craccivora & & Mweke et al. (2018) \\
\hline & Mango scale, Aulacaspis tubercularis & & Sayed and Dunlap (2019) \\
\hline & Mealy bug, Maconellicoccus hirsutus & & Uma Devi et al. (2008) \\
\hline & Mustard aphid, Lipaphis erysimi & & Sajid et al. (2017) \\
\hline & Cabbage aphid, Brevicoryne brassicae & & Akbari et al. (2014) \\
\hline & English Grain Aphid, Sitobion avenae & & Hesketh et al. (2008) \\
\hline & Rose-grain aphid, Metopolophium dirhodum & & Hesketh et al. (2008) \\
\hline & Seychelles scale, Icerya seychellarum & & Sayed and Dunlap (2019) \\
\hline & Wheat aphid, Schizaphis graminum & & Haron et al. (2020) \\
\hline \multirow[t]{12}{*}{ Metarhizium anisopliae } & Corn earworm, Helicoverpa armigera & Lepidoptera & Fite et al. (2019) \\
\hline & Diamondback moth, Plutella xylostella & & Correa-Cuadros et al. (2014) \\
\hline & Coconut beetle, Brontispa longissima & Coleoptera & Hassan et al. (2019) \\
\hline & Yellow fever mosquito, Aedes aegypti & Diptera & Paula et al. (2011) \\
\hline & Bird cherry-oat aphid, Rhopalosiphum padi & Homoptera & Hesketh et al. (2008) \\
\hline & Cowpea aphid, Aphis craccivora & & Mweke et al. (2018) \\
\hline & Mango scale, Aulacaspis tubercularis & & Sayed and Dunlap (2019) \\
\hline & Mustard aphid, Lipaphis erysimi & & Sajid et al. (2017) \\
\hline & Pea aphid, Acyrthosiphon pisum & & Hesketh et al. (2008) \\
\hline & Seychelles scale, Icerya seychellarum & & Sayed and Dunlap (2019) \\
\hline & English grain aphid, Sitobion avenae & & Hesketh et al. (2008) \\
\hline & Rose-grain aphid, Metopolophium dirhodum & & Hesketh et al. (2008) \\
\hline
\end{tabular}

germination, growth, and virulence of EPF (Bugeme et al. 2008; Mishra et al. 2015).

Soil plays a key role in forming insect populations hence the inhabiting EPF. The communities of EPF differ from one location to another, for example, populations of EPF in the arable soils seem to be different than those in barren lands (Devi et al. 2006; Garrido-Jurado et al. 2011). Quesada-Moraga et al. (2007) detected EPF populations in a wide area of Spain, the EPF were isolated from 175 soil samples out of the 244, and only 2 species were found, B. bassiana and M. anisopliae. Clay content and $\mathrm{pH}$ degree were the 2 predictive factors for the prevailing of $B$. bassiana, while the content of organic matter was the influencing factor for the occurrence of $M$. anisopliae. The alkaline sandy soils found to be empty of any fungal species, whereas soil samples rich in organic matter with acidity contained a high density of EPF. Thus, various fungi species inhabit the soil for a part of their life cycle as it can provide a suitable shelter can provide protecting from unsuitable conditions (Toledo et al. 2008) in which the fungi producing conidia to build up their populations. 


\section{Insects as antifungal}

Many peptides that showed antimicrobial activities have been isolated from various sources such as bacteria, fungi, and plants as well as animals. Those antimicrobial peptides (AMPs) vary greatly in their properties. AMPs have different molecular weight that range between 1.3 and $30 \mathrm{kDa}$. They also showed a variable potency and a biological activity spectrum. Most AMPs are heat stable due to the existence of fewer amino acids (Laverty et al. 2011). Many antimicrobial peptides are cationic, named CAPs. More than 1000 CAPs have been fully characterized (Hale and Hancock 2007; Pasupuleti et al. 2012). Naturally derived CAPs are formed of a positive charge between +2 and +9 , due to the presence of a very few acidic residues, like aspartate or glutamate together with many of cationic amino acids including arginine or lysine and/or histidine (Yeung et al. 2011).

The presence of hydrophobic residues, that constitutes about $30-50 \%$ of the whole peptide structure (such as tryptophan or branched amino acids such as valine), plays an important role in providing an amphiphilic structure upon the interaction with membranes (Qiu et al. 2018). This amphiphilic property, together with the existence of a large amount of positive charges, results in the effective antimicrobial activities of CAPs. Any change in the ratios of net charge and hydrophobicity will greatly affect the antimicrobial activity as well as the peptide spectrum towards various microorganisms. Increasing the antimicrobial activity could be increased by adjusting the lipophilic: charge as in the case of glycopeptides. Vancomycin is a glycopeptide that is effective against many methicillin-resistant Staphylococcus aureus strains. Dalbavancin and oritavancin are vancomycin lipoglycopeptide derivatives that showed increased antimicrobial activity against vancomycin-resistant strains (Zelezetsky et al. 2005). The amino acids constituting the CAPs primary sequence are the main factor that affects the antimicrobial spectrum and broad structural diversity (Thomas et al. 2010).

Although CAPs may have different secondary structures, they still share the same basic properties for developing amphipathic structures and being cationic under certain physiological conditions (Maloy and Kari 1995). The secondary structures of the peptides consist of amphiphilic $\beta$-sheet structures with two or three disulfide (stabilizing) bonds, together with an $\alpha$-helical short segment or/and from 2 to $4 \beta$-strands. The formation of disulfide bridges results from a large amount of cysteine found in the primary sequence. $\alpha$-Defensin and $\beta$ defensin are two examples of naturally derived peptides in mammalian host defense system (Wilson et al. 2009). The structure of these peptides is a point of interest since the majority of hydrophobic moieties are found in one face of the helix structure. However, the polar amino acids that play an important role in solubilizing the microbial membranes are located in opposite face of the helix (Schmidt and Wong 2013). Amphipathic $\alpha$ helices are not able to form disulfide bridges due to the absence of cysteine (Shai 2002). Among the peptides found in nature are magainin that is isolated from the skin secretions of certain frog species named Xenopus laevis (Schäfer-Korting and Rolff 2018), also mellitin, which is obtained from honeybee venom (Laverty et al. 2011; Cardoso et al. 2018) as well as the cecropins, which is a group of the dipteran defense insect peptides (Almeida and Pokorny 2012). On the other hands, cyclic peptides are uncommon class of CAPs. These cyclic structures contain $\beta$-turn affected by just a single disulfide bond such as dodecapeptide obtained from bovine neutrophils (Price et al. 2019).

\section{Antifungal peptide groups}

The studies reported some peptides with antifungal activities, as they show their ability to suppress fungal growth or even reproduction. The antifungal peptides are classified on the basis of mechanism of action (Gelotar et al. 2013). The first group of fungal peptides is the amphipathic peptides. This group is widely distributed in nature and gains a lot of importance as antifungal compounds. They are membrane lytic peptides that are characterized mainly by the presence of both hydrophilic and hydrophobic residues. It has 2 surfaces, one is positively charged, while the second surface remained neutral (uncharged) (Fosso et al. 2015). Moreover, some of these peptides cause disturbance of the membrane structure without crossing the membrane itself (Leuschner and Hansel 2004). Additionally, the second group of peptides can disturb the synthesis of the cell wall and it also can disturb the glucan or chitin biosynthesis (Fernández-Carneado et al. 2004). The antifungal agents belong to these 2 structural groups of peptides are considered to be very effective and safe for immunecompromised patients (Desbois et al. 2010). The University of Nebraska Medical Center (USA) has developed an interesting antimicrobial peptides data base (APD). Furthermore, the update of this antimicrobial peptide database (UAPD) provides very helpful information about 1228 peptides, among which 327 are considered antifungal agents (Wang et al. 2009).

\section{Examples for antifungal peptides}

Various biologically active peptides have been found in many insects (Table 2). Interestingly these peptides showed antibacterial and antifungal, as well as antiviral activities (Mishra and Wang 2012). It was reported that insects produce a huge number of different antifungal proteins to be protected against threatening fungal diseases. Many insects exert high antimicrobial activity 
Table 2 Naturally occurring antifungal peptides originated from various insect sources (Schuhmann et al. 2003)

\begin{tabular}{ll}
\hline Peptide & Target(s) \\
\hline Brevinin & Bacteria and yeast \\
Cecropins & Filamentous fungi and bacteria \\
Insect defensins & Filamentous fungi, yeast, and some show activity against bacteria \\
Glycine-rich peptides & Yeast \\
Temporins & Filamentous fungi, yeast, and bacteria \\
Thanatin & Filamentous fungi and bacteria \\
Spinigerin & Filamentous fungi, yeast, and bacteria \\
\hline
\end{tabular}

towards Gram-positive bacteria; however, lower action was detected towards Gram-negative bacteria, fungi, or yeasts (Fu et al. 2009). So far, very few compounds with antifungal activities have been detected in insects. As examples, drosomycin produced from $D$. melanogaster ( $\mathrm{Da}$ Silva et al. 2003), gallerimycin isolated from the greater wax moth "Galleria mellonella" larvae (González-Santoyo and Córdoba-Aguilar 2012), and termicin produced from termites (Khaleel et al. 2013), as well as heliomycin has been found to be produced from the tobacco budworm Heliothis virescens (Fehlbaum et al. 1994).

The studies also showed the production of two types of cecropin from the giant silk moth Hyalopora cecropia. These were named Cecropin A and Cecropin B that were found to be lytic linear peptides. These two peptides showed about 95\% killing effect towards Aspergillus fumigatus and Fusarium oxysporum (Schuhmann et al. 2003). Plus, both peptides have shown a great antifungal activity in acidic medium ( $\mathrm{pH} 5-6)$. However, only cecropin A has exerted antifungal activity at neutral $\mathrm{pH}$. This could be attributed to variation in charge found at the two peptides C-terminus (Pushpanathan et al. 2013). Thanatin and drosomycin are examples of cysteine-rich peptides that are obtained from Podisus maculiveris and Drosophila melanogaster, respectively. Thanatin is a small non-hemolytic peptide that contains 21 residues. When thanatin is found in water, it constitutes an antiparallel sheet structure with a disulfide bridge (Lemaitre et al. 1997).

Thanatin showed its ability to inhibit both A. fumigatus and $F$. oxysporum growth (Van der Weerden et al. 2013). On the other hands, drosomycin is a peptide formed of 44 amino acids and it has twisted threestranded sheet structure stabilized by the presence of disulfide bonds. Drosomycin is very effective against $F$. oxysporum (De Lucca and Walsh 2000).

The antimicrobial peptides in response to fungal or bacterial infections are expressed in the insects' fat body (which is equivalent to liver in the higher animals), while the peptides are then secreted into the hemolymph (equivalent to blood) (Chen et al. 1988). Drosophila showed 2 different pathways in this respect; first, the immune-deficiency pathway (IMD) that begins by Gram-negative bacteria, and second, the stimulation of the Toll-receptor path that was achieved by fungi, yeast, and mold as well as Gram-positive bacteria (Cooper and Eleftherianos 2017). Usually, the antimicrobial peptides produced from insects after bacterial threatening and that explains the occurrence of fewer antifungal molecules. In response to both in vitro and in vivo antifungal activity, insects can show high production of peptides (Taylor et al. 2008).

\section{Insect's immunology}

The vital mechanisms controlling the insect immune response as well as their consequence on the human immunology have attracted the attention of many scientists recently. For any insect to resist various pathogens infection, innate immunity is required and important. There are many barriers that protect the insects. The insect exoskeleton prevents the trachea membrane and the stomodeum. Moreover, insects produce some antimicrobial peptides, which are secreted into hemolymph (Faye and Hultmark 1993). The drosophila is an example that comprises a wide range of potent antifungal and antibacterial peptides including attacin, cecropin, diptericin, drosocin, and drosomycin as well as metchnikowin, where they are originated from the fat body. Additionally, there is a cellular response, characterized by the presence of hemocytes that resulted in the phagocytosis of foreign objects as well as microorganisms and other parasites (Brivio et al. 2010). Finally, this was followed by an activation of a proteolytic cascade in the hemolymph, which in turn resulted in the activation of phenol oxidase, the enzyme responsible for the melanin formation, which is finally deposited on the invading parasites.

\section{Conclusion}

The history of using EPF, their killing mechanism, host range, and the factors affecting their virulence were studied to accomplish their use as biocontrol agents. Moreover, highlights on the role of insect's immunology and some insect's products as antifungal agents were 
presented focusing on peptides and their biological activities against fungi. Survey work should be undertaken in different geographical regions to isolate and identify virulent fungal pathogens. Antifungal peptides play an important role in protection against fungal infection via an innate defense mechanism. Utilizing different antimicrobial peptide creates a strategy for the production of low-cost antimicrobial agent. Additionally, more detailed studies are required to explain the configuration of these peptides that helps in supplying more information for computer simulation methods to figure out the antifungal mechanism at the atomic level.

\section{Abbreviations}

EPF: Entomopathogenic fungi; IPM: Integrated pest management; AMPs: Antimicrobial peptides; CAPs: Cationic antimicrobial peptides; APD: Antimicrobial peptides data base; UAPD: Updated antimicrobial peptide database (UAPD); IMD: Immune-deficiency pathway

\section{Acknowledgements}

Not applicable.

\section{Authors' contributions}

WE and GD have substantially contributed to the conception and design of the article. ME and GD have contributed in writing insect as antifungal section. WE and KM have contributed in writing fungi as antiinsect section, All authors have read, revised, and approved the manuscript.

\section{Funding}

Not applicable.

\section{Availability of data and materials}

Not applicable.

Ethics approval and consent to participate

Not applicable.

\section{Consent for publication}

Not applicable.

\section{Competing interests}

The authors declare that they have no competing interests.

\section{Author details}

${ }^{1}$ Chemistry of Natural and Microbial Products Department, Pharmaceutical Industries Division, National Research Centre, Dokki, Giza 12622, Egypt. ${ }^{2}$ Economic Entomology Department, Faculty of Agriculture, Kafrelsheikh University, Kafr El-Sheikh 33-516, Egypt.

Received: 17 September 2020 Accepted: 29 December 2020 Published online: 10 January 2021

\section{References}

Akbari S, Safavi S, Ghosta Y (2014) Efficacy of Beauveria bassiana (Blas.) Vuill. against cabbage aphid Brevicoryne brassicae L. (Hem.: Aphididae) in laboratory condition. Arch Phytopath Plant Protect 47(12):1454-1458 Almeida P, Pokorny A (2012) Comprehensive biophysics. Academic Press, Cambridge, pp 189-222

Alves da Silva R, Dias Quintela E, Moura Mascarin G, Pedrini N, Moraes Lião L, Henrique FP (2015) Unveiling chemical defense in the rice stalk stink bug against the entomopathogenic fungus Metarhizium anisopliae. J Invertebr Pathol. 127:93-100

Ambethgar V (2009) Potential of entomopathogenic fungi in insecticide resistance management (IRM): A review. J Biopestic. 2(2):177-193

Amparyup P, Charoensapsri W, Tassanakajon A (2013) Prophenoloxidase system and its role in shrimp immune responses against major pathogens. Fish Shellfish Immunol. 34(4):990-1001
Audoin V (1837) Nouvelles expériences sur la nature de la maladie contagieuse qui attaque les Vers a' soie, et qu'on désigne sous le nom de Muscardine. Ann. Sci. Nat. 8:257-270

Biswas C, Dey P, Satpathy S, Satya P, Mahapatra BS (2013) Endophytic colonization of white jute (Corchorus capsularis) plants by different Beauveria bassiana strains for managing stem weevil (Apion corchori). Phytoparasit. 41: $17-21$

Brivio M, Mastore M, Nappi A (2010) A pathogenic parasite interferes with phagocytosis of insect immunocompetent cells. Dev Comp Immunol. 34: 991-998

Bruck DJ, Lewis LC (2002) Carpophilus freemani (Coleoptera: Nitidulidae) as a vector of Beauveria bassiana. J Invertebr Pathol. 80:188-190

Bugeme DM, Maniania NK, Knapp M, Boga HI (2008) Effect of temperature on virulence of Beauveria bassiana and Metarhizium anisopliae isolates to Tetranychus evansi. Exp Appl Acarol. 46:275-285

Butt TM (2002) Use of entomogenous fungi for the control of insect pests. In Agricultural applications. Springer, Berlin, Heidelberg, pp 111-134

Cagáň L', Uhlík V (1999) Pathogenicity of Beauveria bassiana strains isolated from Ostrinia nubilalis Hbn. (Lepidoptera: Pyralidae) to original host and to ladybirds (Coleoptera: Coccinellidae). Plant Protect Sci 35:108-112

Cardoso M, Oshiro K, Rezende S, Cândido ES, Franco OL (2018) The structure/ function relationship in antimicrobial peptides: what can we obtain from structural data? In Advances in protein chemistry and structural biology (Elsevier), pp 359-384

Chen H-C, Brown JH, Morell JL, Huang CM (1988) Synthetic magainin analogues with improved antimicrobial activity. FEBS Lett. 236(462):466

Cooper D, Eleftherianos I (2017) Memory and specificity in the insect immune system: current perspectives and future challenges. Front Immunol. 8:539

Correa-Cuadros JP, Rodríguez-Bocanegra M, Sáenz-Aponte A (2014) Susceptibility of Plutella xylostella (Lepidoptera: Plutellidae; Linnaeus 1758) to Beauveria bassiana Bb9205, Metarhizium anisopliae Ma9236 and Heterorhabditis bacteriophora HNI0100. Univ. Sci. 19(3):277-285

Da Silva P, Jouvensal L, Lamberty M, Bulet P, Caille A, Vovelle F (2003) Solution structure of termicin, an antimicrobial peptide from the termite Pseudacanthotermes spiniger. Protein Sci. 12:438-446

De Lucca A, Walsh T (2000) Antifungal peptides: origin, activity, and therapeutic potential. Rev Iberoam Micol. 17:116-120

Desbois AP, Gemmell CG, Coote PJ (2010) In vivo efficacy of the antimicrobia peptide ranalexin in combination with the endopeptidase lysostaphin against wound and systemic meticillin-resistant Staphylococcus aureus (MRSA) infections. Int J Antimicrob Ag. 35:559-565

Devi K, Rao C, Allee A (2006) Effect in the infection dynamics of the entomopathogenic Fungus Beauveria bassiana (Bals) Vuill. on the beetle, Mylabris pustulata. Mycopathol 161(6):385-394

Faria MR, Wraight SP (2007) Mycoinsecticides and mycoacaricides: a comprehensive list with worldwide coverage and international classification of formulation types. Biol Control 43(3):237-256

Faye I, Hultmark D (1993) The insect immune proteins and the regulation of their genes. Para Patho Insec. 2:25-53

Fehlbaum P, Bulet P, Michaut L, Lagueux M, Broekaert W, Hetru C, Hoffmann J (1994) Insect immunity. Septic injury of Drosophila induces the synthesis of a potent antifungal peptide with sequence homology to plant antifungal peptides. J Biol Chem 269:33159-33163

Fernández-Carneado J, Kogan M, Pujals S, Giralt E (2004) Amphipathic peptides and drug delivery. Peptide Science: Original Research on Biomolecules 76: 196-203

Fite T, Icon T, Tefera M, Negeri T, Damte WS (2019) Evaluation of Beauveria bassiana, Metarhizium anisopliae, and Bacillus thuringiensis for the management of Helicoverpa armigera (Hubner) (Lepidoptera: Noctuidae) under laboratory and field conditions. Bio Sci Technol. 30(3):278-295

Fosso M, AlFindee M, Zhang Q, Nziko V, Kawasaki Y, Shrestha S, Bearss J, Gregory R, Takemoto J, Chang C-W (2015) Structure-activity relationships for antibacterial to antifungal conversion of kanamycin to amphiphilic analogues. J org chem. 80:4398-4411

Fu P, Wu J, Guo G (2009) Purification and molecular identification of an antifungal peptide from the hemolymph of Musca domestica (housefly). Cell Mol Immunol. 6:245-251

Garrido-Jurado I, Torrent J, Barrón V, Corpas A, Quesada-Moraga E (2011) Soil properties affect the availability, movement, and virulence of entomopathogenic fungi conidia against puparia of Ceratitis capitata (Diptera: Tephritidae). Biol Cont. 58:277-285 
Gelotar P, Vachhani S, Patel B, Makwana N (2013) The prevalence of fungi in fingernail onychomycosis. J Clin Diagno Res 7:250

Goettel MS, Inglis GD, Wraight SP (2000) In: Lacey LA, Kaya HK (eds) Fungi, in field manual in Invertebrate Pathology. Kluwer Academic Press, Dordrecht, The Netherlands, pp 255-282

González-Santoyo I, Córdoba-Aguilar A (2012) Phenoloxidase: a key component of the insect immune system. Entomol Exp Appl. 142:1-16

Gryganskyi A, Humber R, Smith M, Hodge K, Huang B, Voigt K (2013) Phylogenetic lineages in Entomophthoromycota. Persoonia 30:94-105

Hageskal G, Knutsen AK, Gaustad P, De Hoog GS, Skaar I (2006) Diversity and significance of mold species in Norwegian drinking water. Appl. Environ. Microbiol. 72:7586-7593

Hajdušek O, Sima R, Ayllon N, Jalovecka M, Perner J, de la Fuente J (2013) Interaction of the tick immune system with transmitted pathogens. Front Cell Infect Microbiol. 3:26

Hajek AE, Goettel MS (2007) Guidelines for evaluating effects of entomopathogens on non-target organisms. In: Lacey LA, Kaya HK (eds) Field manual of techniques in invertebrate pathology. Springer Netherlands, Dordrecht, pp 816-833

Hale JD, Hancock RE (2007) Alternative mechanisms of action of cationic antimicrobial peptides on bacteria. Expert Rev Anti-Infective Ther 5:951-959

Haron N, Ahmed M, Ali S, Abas A, Elshaier M (2020) Evaluate the effects of entomopathogenic fungi isolates on Wheat Aphid, Schizaphis graminum (Rondani) (Hemiptera: Aphididae). EAJBSA 13(2):149-159

Hassan FR, Abdullah SK, Assaf LH (2019) Pathogenicity of the entomopathogenic fungus, Beauveria bassiana (Bals.) Vuill. endophytic and a soil isolate against the squash beetle, Epilachna chrysomelina (F.) (Coleoptera: Coccinellidae). Egypt J Biol Pest Control 29:74

Hesketh H, Alderson P, Pye B, Pell J (2008) The development and multiple uses of a standardized bioassay method to select hypocrealean fungi for biological control of aphids. Biol Control. 46(2):242-255

Hou CX, Qin GX, Liu T, Mei XL, Li B, Shen ZY, Guo XJ (2013) Differentially expressed genes in the cuticle and hemolymph of the silkworm, Bombyx mori, injected with the fungus Beauveria bassiana. J Insect Sci 13:138

Jaronski ST, Mascarin GM (2017) Mass production of fungal entomopathogens. In Microbial control of insect and mite pests. Academic Press, pp 141-155

Khaleel A, Nawaz M, Hindawi B (2013) Sol-gel derived Cr (III) and Cu (II)/Y-Al2O3 doped solids: effect of the dopant precursor nature on the structural, textural and morphological properties. Mater Res Bull. 48:1709-1715

Klinger E, Eleanor G, Francis D (2006) Beauveria bassiana horizontal infection between cadavers and adults of the Colorado Potato Beetle, Leptinotarsa decemlineata (Say). Environment Entomol 35(4):992-1000

Laverty G, Gorman S, Gilmore BF (2011) The potential of antimicrobial peptides as biocides. Inter J molecul sci. 12:6566-6596

Lavine MD, Strand M (2002) Insect hemocytes and their role in immunity. Insect Biochem. Mol. Biol. 32(10):1295-1309

Leao MP, Tiago PV, Andreote FD, de Araujo WL, de Oliveira NT (2015) Differential expression of the pr1A gene in Metarhizium anisopliae and Metarhizium acridum across different culture conditions and during pathogenesis. Genet. Mol. Biol. 38:86-92

Lemaitre B, Reichhart J-M, Hoffmann JA (1997) Drosophila host defense: differential induction of antimicrobial peptide genes after infection by various classes of microorganisms. Proc Nat Acad Sci. 94:14614-14619

Leuschner C, Hansel W (2004) Membrane disrupting lytic peptides for cancer treatments. Curr pharm des. 10:2299-2310

Lopez DC, Zhu-Salzman K, Ek-Ramos MJ, Sword GA (2014) The entomopathogenic fungal endophytes Purpureocillium lilacinum (formerly Paecilomyces lilacinus) and Beauveria bassiana negatively affect cotton aphid reproduction under both greenhouse and field conditions. PLoS One. 9:e103891

Maina UM, Galadima IB, FM Gambo FM, Zakaria D. (2018) A review on the use of entomopathogenic fungi in the management of insect pests of field crops. J Entomol Zool Studies 6(1):27-32

Maloy WL, Kari UP (1995) Structure-activity studies on magainins and other host defense peptides. Biopolymers 37:105-122

Maurer P, Couteaudier Y, Girard P, Bridge P, Riba G (1997) Genetic diversity of Beauveria bassiana and relatedness to host insect range. Mycol Res. 101:159-164

Meyling NV, Lubeck M, Buckley EP, Eilenberg J, Rehner SA (2009) Community composition, host range and genetic structure of the fungal entomopathogen Beauveria in adjoining agricultural and semi natural habitats. Mol Ecol. 18:1282-1293
Mishra B, Wang G (2012) Ab initio design of potent anti-MRSA peptides based on database filtering technology. J Am Chem Soc. 134:12426-12429

Mishra S, Kumar P, Malik A (2015) Effect of temperature and humidity on pathogenicity of native Beauveria bassiana isolate against Musca domestica L. J Parasitic Dis 39(4):697-704

Moonjely S, Barelli L, Bidochka MJ. 2016. Insect pathogenic fungi as endophytes. In: St Leger RJ, editor. Advances in genetics. Academic Press; pp. 107-135.

Mweke A, Ulrichs C, Nana P (2018) Evaluation of the entomopathogenic fungi Metarhizium anisopliae, Beauveria bassiana, and Isaria sp. for the management of Aphis craccivora (Hemiptera: Aphididdae). J Econ Entomol 111(4):1587-1594

Nolard N (2004) Allergy to moulds. BCCM Newsletter 16:1-3

Ocampo-Hernández JA, Tamayo-Mejía F, Tamez-Guerra P, Gao Y, Guzmán-Franco AW (2019) Different host plant species modifies the susceptibility of Bactericera cockerelli to the entomopathogenic fungus Beauveria bassiana. J Appl Entomol. 143:984-991

Olivera RC, Neves PM (2004) Biological control compatibility of Beauveria bassiana with acaricides. Neotrop Entomol. 33:353-358

Pasteur L (1874) Observations (au sujet des conclusions de M. Dumas) relatives au phylloxera. Comptes rendus hebdomadaires des séances de l'Académie des Sci 79:1233-1234

Pasupuleti M, Schmidtchen A, Malmsten M (2012) Antimicrobial peptides: key components of the innate immune system. Crit Rev Biotechnol. 32:143-171

Paula AR, Carolino AT, Silva CP, Samuels RI (2011) Susceptibility of adult female Aedes aegypti (Diptera: Culicidae) to the entomopathogenic fungus Metarhizium anisopliae is modified following blood feeding. Parasites Vector. 4:91

Pedrini N, Ortiz-Urquiza A, Huarte-Bonnet C, Zhang S, Keyhani NO (2013) Targeting of insect epicuticular lipids by the entomopathogenic fungus Beauveria bassiana: hydrocarbon oxidation within the context of a host pathogen interaction. Front Microbiol. 4:24

Price RL, Bugeon L, Mostowy S, Makendi C, Wren B, Williams H, Willcocks S (2019) In vitro and in vivo properties of the bovine antimicrobial peptide, Bactenecin 5. Plos One 14:e0210508

Pushpanathan M, Gunasekaran P, Rajendhran J (2013) Antimicrobial peptides: versatile biological properties. Int J Pept 675391:1-15

Qiu F, Chen Y, Tang C, Zhao X (2018) Amphiphilic peptides as novel nanomaterials: design, self-assembly and application. Int J Nanomed. 13:5003

Quesada-Moraga E, Navas-Cortes E, Maranhao E, Ortiz-Urquiza A, Santiago-Alvarez C (2007) Factors affecting the occurrence and distribution of entomopathogenic fungi in natural and cultivated soils. Mycol Res. 111:947966

Ramanujam B, Rangeshwaran R, Sivakmar G, Mohan M, Yandigeri MS (2014) Management of insect pests by microorganisms. Proc Indian National Sci Acad. 80(2):455-471

Ravensberg W (2015) Crop protection in 2030: towards a natural, efficient, safe and sustainable approach. In: International Symposium on Biopesticides, Swansea University, pp 7-9

Rehner SA, Buckley E (2005) Beauveria phylogeny inferred from nuclear IST and EFl-asequences: evidence for cryptic diversification and links to Cordyceps teleomorphs. Mycol. 97:84-98

Sahayaraj K, Karthick Raja NS (2011) Field evaluation of three entomopathogenic fungi on groundnut pests. Tropicultura 29(3):143-147

Sajid M, Bashir N, Batool Q, Munir I, Bilal M, Jamal A, Munir S (2017) In-vitro evaluation of biopesticides (Beauveria bassiana, Metarhizium anisopliae, Bacillus thuringiensis) against mustard aphid Lipaphis erysimi kalt. (Hemiptera: Aphididae). JEZS 5(6):331-335

Santi L, Beys da Silva W, Berger M, Guimarães J, Schrank A, Vainstein M (2010) Conidial surface proteins of Metarhizium anisopliae: Source of activities related with toxic effects, host penetration and pathogenesis. Toxicon 55: 874-880

Sayed A, Dunlap CA (2019) Virulence of some entomopathogenic fungi isolates of Beauveria bassiana (Hypocreales: Cordycipitaceae) and Metarhizium anisopliae (Hypocreales: Clavicipitaceae) to Aulacaspis tubercularis (Hemiptera: Diaspididae) and Icerya seychellarum (Hemiptera: Monophlebidae) on Mango Crop. J Econ Entomol. 112(6):2584-2596

Schäfer-Korting M, Rolff J (2018) Skin delivery of antimicrobial peptides. Emerging Nanotechnol Immunol., (Elsevier), pp 23-45

Schmidt NW, Wong GC (2013) Antimicrobial peptides and induced membrane curvature: geometry, coordination chemistry, and molecular engineering. Curr Opin Solid State Mater Sci. 17:151-163 
Schuhmann B, Seitz V, Vilcinskas A, Podsiadlowski L (2003) Cloning and expression of gallerimycin, an antifungal peptide expressed in immune response of greater wax moth larvae, Galleria mellonella. Arch Insect Biochem Physiol 53:125-133

Shahid A, Rao A, Bakhsh A, Husnain T (2012) Entomopathogenic fungi as biological controllers: new insights into their virulence and pathogenicity. Arch Biol Sci Belgrade 64(1):21-42

Shai Y (2002) From innate immunity to de-novo designed antimicrobial peptides. Curr Pharma Design 8:715-725

Sufyan M, Abbasi A, Wakil W (2019) Efficacy of Beauveria Bassiana and Bacillus Thuringiensis against Maize Stem Borer Chilo Partellus (Swinhoe) (Lepidoptera: Pyralidae). Gesunde Pflanzen 71:197-204

Sujeetha JA, Sahayaraj K (2014) Role of entomopathogenic fungus in pest management. In Basic and applied aspects of biopesticides. Springer, New Delhi, pp 31-46

Tawara S, Ikeda F, Maki K, Morishita Y, Otomo K, Teratani N, Goto T, Tomishima M, Ohki H, Yamada A (2000) In vitro activities of a new lipopeptide antifungal agent, FK463, against a variety of clinically important fungi. Antimicrob Agents Chemother. 44:57-62

Taylor K, Barran PE, Dorin JR (2008) Structure-activity relationships in $\beta$-defensin peptides. Pep Sci. 90:1-7

Thomas S, Karnik S, Barai RS, Jayaraman VK, Idicula-Thomas S (2010) CAMP: a useful resource for research on antimicrobial peptides. Nucleic Acids Res. 38 : D774-D780

Toledo J, Liedo P, Flores S, Campos SE, Villaseñor A, Montoya P, Sugayama R, Zucchi R, Ovruski S, Sivinski J (2008) Use of Beauveria bassiana and Metarhizium anisopliae for fruit fly control: a novel approach. In: RL Sugayama RA, Zucchi SMO, Sivinski J (eds) Fruit flies of economic importance: from basic to applied knowledge. Press Color Gráficos Especializados Ltda, Salvador, Brazil, pp 127-132

Ullah MI, Altaf N, Afzal M, Arshad M, Mehmood N, Riaz M, Majeed S, Ali S, Abdullah A (2019) Effects of entomopathogenic fungi on the biology of Spodoptera litura (Lepidoptera: Noctuidae) and its reduviid predator, Rhynocoris marginatus (Heteroptera: Reduviidae). Int J Insect Sci 11: 1179543319867116

Uma Devi K, Padmavathia J, Uma C, Maheswara R, Akbar A, Khanc P, Murali C, Mohand (2008) A study of host specificity in the entomopathogenic fungus Beauveria bassiana (Hypocreales, Clavicipitaceae). Biocontrol Sci Technol 18(9/10):975-989

Van der Weerden NL, Bleackley MR, Anderson MA (2013) Properties and mechanisms of action of naturally occurring antifungal peptides. Cell Mol Life Sci. 70:3545-3570

Vega FE, Goettel M, Blackwell M, Chandler D, Jackson M, Keller M, Koike NK, Maniania A, Monzon B, Ownley JK, Pell DE, Rangel HE (2009) Fungal entomopathogens: new insights on their ecology. Fungal ecol. 2:149-159

Wang G, Li X, Wang Z (2009) APD2: the updated antimicrobial peptide database and its application in peptide design. Nucleic acids res. 37:D933-D937

Wilson CL, Schmidt A, Pirilä E, Valore EV, Ferri N, Sorsa T, Ganz T, Parks WC (2009) Differential processing of $\alpha$-and $\beta$-defensin precursors by matrix metalloproteinase-7 (MMP-7). J Biol Chem. 284:8301-8311

Yeung AT, Gellatly SL, Hancock RE (2011) Multifunctional cationic host defence peptides and their clinical applications. Cell Mol Life Sci. 68:2161

Zelezetsky I, Pag U, Sahl H-G, Tossi A (2005) Tuning the biological properties of amphipathic a-helical antimicrobial peptides: rational use of minimal amino acid substitutions. Pept. 26:2368-2376

Zimmermann G (2007) Review on safety of the entomopathogenic fungi Beauveria bassiana and Beauveria brongniartii. Biocontrol Sci Technol. 17(5/6): $553-596$

\section{Publisher's Note}

Springer Nature remains neutral with regard to jurisdictional claims in published maps and institutional affiliations.

\section{Submit your manuscript to a SpringerOpen ${ }^{\circ}$ journal and benefit from:}

- Convenient online submission

- Rigorous peer review

- Open access: articles freely available online

- High visibility within the field

- Retaining the copyright to your article

Submit your next manuscript at $\boldsymbol{\nabla}$ springeropen.com 